\title{
KOMPARASI MODEL PEMBELAJARAN KOOPERATIF TIPE THINK PAIR SHARE DAN KOOPERATIF TIPE STUDENT TEAMS ACHIEVEMENT DIVISION TERHADAP HASIL BELAJAR SISWA DALAM PEMBELAJARAN IPA
}

\author{
N. K. Mawar, I. N. Suardana, P. P. Juniartina \\ Program Studi S1 Pendidikan IPA \\ Universitas Pendidikan Ganesha \\ Singaraja, Indonesia \\ e-mail:\{komang.mawar,nyoman.suardana,juniartina.prima\}@undiksha.ac.id
}

\begin{abstract}
Abstrak
Penelitian ini bertujuan menganalisis perbedaan hasil belajar IPA antara siswa yang dibelajarkan menggunakan model pembelajaran kooperatif tipe think pair share dan model pembelajaran kooperatif tipe student teams achievement division. Jenis penelitian ini adalah quasi experimental dengan rancangan Nonequivalent Pretest-Posttest Control Group Design. Populasi penelitian ini adalah seluruh siswa kelas VII SMP Negeri 6 Singaraja semester genap tahun ajaran 2017/2018 yang berjumlah 304 orang. Pengambilan sampel dilakukan dengan teknik cluster random sampling. Sampel penelitian ini adalah siswa kelas VII A3 yang berjumlah 32 siswa sebagai kelas eksperimen 1 dan siswa kelas VII B2 yang berjumlah 26 siswa sebagai kelas eksperimen 2. Objek penelitian ini adalah hasil belajar IPA siswa. Data hasil belajar IPA diperoleh melalui tes pilihan ganda. Data dianalisis secara deskriptif untuk mendeskripsikan hasil belajar IPA siswa dan dianalisis secara inferensial dengan uji ANCOVA 1 jalur dengan taraf signifikansi 0,05 . Hasil penelitian ini menunjukkan bahwa terdapat perbedaan hasil belajar IPA siswa yang dibelajarkan menggunakan model pembelajaran kooperatif tipe TPS dan model pembelajaran kooperatif tipe STAD. Nilai rata-rata yang diperoleh siswa pada kelas kooperatif tipe TPS dan kooperatif tipe STAD secara berturut-turut sebesar 80,46 dan 62,34.
\end{abstract}

Kata Kunci: Hasil Belajar, Kooperatif Tipe Think Pair Share, Kooperatif Tipe Student Teams Achievement Division

\begin{abstract}
This study aims to analyze the difference of science learning outcomes between students who were taught using cooperative learning model of Think Pair Share type and Student Teams Achievement Division type cooperative learning model. This type of research is quasi experimental with Nonequivalent Pretest-Posttest Control Group Design. The population of this study is all students of class VII SMP Negeri 6 Singaraja grade of the academic year 2017/2018 which amounted to 304 people. Sampling was done by cluster random sampling. The sample of this study is the students of class VII A3 which amounted to 32 students as an experiment class 1 and students of class VII B2 which amounted to 26 students as an experiment class. The object of this research is the result of science learning of students. The data of IPA learning result is obtained through multiple choice test. Data were analyzed descriptively to describe students' IPA learning outcomes and analyzed inferentially with one-way ANCOVA test with 0.05 significance level. The results of this study indicate that there are differences in learning outcomes of students' knowledge that is learned using cooperative learning model of TPS type and STAD type cooperative learning model. The average scores obtained by students in cooperative class type TPS and cooperative type STAD are 80.46 and 62.34 respectively.
\end{abstract}

Keywords: Learning outcomes, Kooperatif Tipe Think Pair Share, Kooperatif Tipe Student Teams Achievement Division 


\section{PENDAHULUAN}

Undang-Undang Nomor 20 Tahun 2003 tentang Sistem Pendidikan Nasional Pasal 1 Ayat 1 menyatakan bahwa pendidikan adalah usaha sadar dan terencana untuk mewujudkan suasana belajar dan proses pembelajaran agar peserta didik secara aktif mengembangkan potensi dirinya untuk memiliki kekuatan spiritual keagamaan, pengendalian diri, kepribadian, kecerdasan, akhlak mulia, serta keterampilan yang diperlukan dirinya, masyarakat, bangsa dan negara. Pendidikan diharapkan dapat membangun karakter dan wawasan peserta didik yang menjadi landasan penting bagi upaya untuk memelihara persatuan dan kesatuan bangsa. Hal ini tidak lepas dari mutu pendidikan yang ditentukan oleh kualitas sumber daya manusia yang dimilikinya.

Sehubungan dengan hal tersebut, berbagai upaya telah dilaksanakan pemerintah untuk meningkatkan mutu pendidikan di Indonesia diantaranya adalah menetapkan Kurikulum 2013 yang merupakan penyempurnaan dari Kurikulum Tingkat Satuan Pendidikan (KTSP), peningkatan kualitas guru melalui kegiatan sertifikasi, pelatihan profesi guru (PPG), pengadaan buku sekolah elektronik (BSE), dan pemberian bantuan berupa bantuan operasional sekolah (BOS). Berbagai upaya tersebut diharapkan dapat memberikan pengaruh yang positif terhadap kualitas pendidikan di Indonesia.

Kenyataan di lapangan, usahausaha pemerintah untuk meningkatkan mutu pendidikan ternyata belum mampu memberikan hasil yang diharapkan sebagaimana mestinya. Hal ini dibuktikan dari data hasil studi PISA tahun 2015 yang menunjukkan bahwa Indonesia mengalami penurunan kualitas pendidikan tiap tahunnya. Hasil studi PISA tahun 2015 menyebutkan bahwa Indonesia menduduki peringkat 59 dari 69 Negara. Hal serupa juga terlihat dari data TIMSS tahun 2015 menunjukkan bahwa Indonesia berada pada ranking 36 dari 49 negara. Hal ini menunjukkan bahwa skor tes sains siswa Indonesia menurun hingga mencapai 21 angka dibandingkan tahun 2011. Bukti lain yang menunjukkan bahwa kualitas pendidikan di Indonesia masih rendah terlihat dari nilai Ujian Nasional tingkat SMP/MTs se-Indonesia yang mengalami penurunan khususnya pada mata pelajaran IPA. Terbukti dari data nilai UN tahun 2017 se-Indonesia pada mata pelajaran IPA mengalami penurunan angka sebesar 4,07 pada tahun 2017 dibandingkan dengan tahun 2016 (Konferensi Pers UN 2017). Hal serupa juga terjadi di Bali tahun 2017. Data nilai UN se-Bali menunjukkan penurunan nilai Ujian Nasional pada mata pelajaran IPA sebesar 7,66 pada tahun 2017 dibandingkan dengan tahun 2016 (Disdikpora Provinsi Bali). Penurunan nilai Ujian Nasional di Indonesia khususnya di Bali mencerminkan adanya permasalahan pada proses pembelajaran di tingkat SMP/ MTs di Bali yang berdampak pada hasil belajar siswa.

Penurunan kualitas pendidikan di Indonesia khususnya di Bali disebabkan oleh lemahnya proses pembelajaran serta peserta didik kurang didorong untuk mengembangkan kemampuan berpikir dalam proses pembelajaran, sehingga hasil belajar siswa menjadi rendah. Hal tersebut senada dengan yang dinyatakan oleh Surayya (2014) bahwa proses pembelajaran di dalam kelas masih diarahkan kepada kemampuan anak untuk menghafal informasi tanpa dituntut untuk memahami informasi yang diingatnya untuk dihubungkan dengan kehidupan sehari-hari. Hasil yang baik diperoleh dari penguasaan materi yang baik pula. Materi pelajaran dapat dikuasai oleh siswa apabila dalam proses pembelajaran siswa memiliki motivasi yang tinggi untuk mempelajari materi.

Orientasi pembelajaran dikelas masih bersifat teacher centered. Zamroni dalam Lubis (2012) menyatakan bahwa teacher centered merupakan suatu instruksi dalam pembelajaran yang berpusat pada guru. Guru berperan sepenuhnya dalam pembelajaran, sehingga peserta didik tidak berkesempatan untuk mengembangkan pengetahuan mereka sendiri karena 
setiap masalah-masalah yang muncul dalam pembelajaran akan diselesaikan oleh guru, sehingga peserta didik menjadi pasif, sedangkan model pembelajaran yang digunakan oleh guru harus membuat siswa aktif dalam proses pembelajaran. Perlu adanya perubahan paradigma dalam menelaah proses belajar mengajar dan interaksi antara siswa dan guru. Sudah seharusnya kegiatan belajar mengajar juga lebih mempertimbangkan siswa. Karena siswa bukanlah sebuah kertas kosong yang bisa diisi dengan berbagai macam informasi dan pengetahuan yang dianggap penting oleh guru.

Bamoro (2015) menyatakan bahwa tugas guru adalah mengorganisir dan mengatur lingkungan pembelajaran di kelas, dengan demikian perlu dikembangkan model pembelajaran yang berorientasi pada pencapaian iklim kondusif untuk mampu bekerja sama, sehingga para siswa diharapkan dapat saling berbagi pengetahuan. Berdasarkan konteks ini pembelajaran yang menekankan pada pembelajaran bersama menjadi sangat penting. Oleh karena itu, kegiatan pembelajaran yang dapat mengasah kemampuan bekerjasama siswa adalah dengan menggunakan model pembelajaran kooperatif.

Model pembelajaran kooperatif adalah salah satu model pembelajaran yang berfokus pada penggunaan kelompok untuk bekerjasama dalam memaksimalkan kondisi belajar agar tujuan belajar dapat tercapai, selain itu model ini juga dapat memotivasi siswa untuk lebih aktif dalam kegiatan proses belajar mengajar sehingga dapat meningkatkan hasil belajar siswa (Slavin, 2005). Model pembelajaran kooperatif yang dapat digunakan untuk meningkatkan hasil belajar siswa adalah model kooperatif tipe think pair share (TPS) dan model kooperatif tipe student teams achievement division (STAD). Kedua metode ini dapat mendorong siswa untuk lebih dinamis, aktif, dan dapat memotivasi siswa untuk lebih semangat dalam proses belajar mengajar sehingga dapat meningkatkan hasil belajar siswa.

Asyah (2014) menyatakan bahwa model pembelajaran kooperatif tipe think pair share menghendaki siswa bekerja saling membantu dalam kelompok kecil dan lebih dicirikan oleh penghargaan kooperatif daripada penghargaan individu. Model pembelajaran kooperatif tipe think pair share sangat ideal digunakan untuk mengajar siswa SMP, karena kecenderungan siswa SMP yang senang berkelompok dengan teman sebaya dan memiliki tingkat kebersamaan yang tinggi. Model ini juga memiliki prosedur yang memberi siswa waktu lebih banyak untuk berpikir sehingga siswa dapat mengalami kejadian langsung dalam proses pembelajaran sehingga hasil belajar dapat meningkat.

Karlina (2015) menyatakan bahwa model kooperatif STAD merupakan salah satu metode atau pendekatan dalam pembelajaran kooperatif yang sederhana dan baik, apalagi untuk guru yang baru mulai menggunakan pendekatan kooperatif dalam kelas, karena dengan strategi Kooperatif STAD yang memiliki enam langkah pembelajaran dapat membuat siswa untuk lebih lama berpikir secara mendalam yaitu berpikir secara individu dan berpikir dengan kelompoknya dalam mendiskusikan jawaban dari pertanyaan-pertanyaan yang diberikan oleh guru. Model pembelajaran kooperatif tipe STAD merupakan salah satu model pembelajaran yang dapat menuntut siswa mampu menguasai konsep dan mengaplikasikannya dalam kehidupan sehari-hari sehingga dapat meningkatkan hasil belajar.

Berdasarkan pemaparan di atas, terlihat bahwa penggunaan model kooperatif tipe TPS dan model kooperatif tipe STAD menunjukkan hasil yang positif terhadap siswa. Oleh karena itu, peneliti tertarik untuk mengkomparasikan model pembelajaran tipe TPS dan model pembelajaran kooperatif tipe STAD terhadap hasil belajar siswa.

\section{METODE}

Penelitian ini merupakan penelitian eksperimen semu (quasi eksperimen) dengan rancangan Nonequivalent PretestPosttest Control Group Design. Populasi dalam penelitian ini adalah seluruh siswa kelas VII SMP Negeri 6 Singaraja semester genap tahun ajaran 2017/2018 
yang berjumlah 304 orang. Pengambilan sampel dilakukan dengan teknik cluster random sampling. Dari hasil pengundian diperoleh sampel pada siswa kelas VII A3 sebagai kelas eksprimen 1 dengan model kooperatif TPS dan siswa kelas VII B2 sebagai kelas eksperimen 2 dengan model kooperatif STAD.

Objek penelitian ini adalah hasil belajar siswa pada mata pelajaran IPA. Metode pengumpulan data yang digunakan adalah metode tes. Tes yang digunakan adalah tes pilihan ganda (multiple choice). Karakteristik tes yang digunakan dalam penelitian ini adalah tes yang sudah divalidasi oleh dua orang dosen pembimbing, memiliki indeks daya beda lebih dari 0,20, indeks kesukaran tes berada pada rentangan 0,30 sampai 0,70, memiliki reliabilitas tes lebih dari 0,05, dan konsistensi internal butir lebih besar dari $r$ tabel 0,184 . Hasil pengujian instrumen adalah tes hasil belajar IPA yang berjumlah 30 butir soal yang mewakili semua indikator dalam hasil belajar. Tes ini digunakan untuk mengukur kemampuan awal siswa (pretest) dan hasil belajar IPA siswa (posttest).

Penelitian ini menggunakan dua metode analisis data, yaitu analisis deskriptif dan analisis ANCOVA 1 jalur dengan taraf signifikansi 0,05. Metode analisis deskriptif digunakan untuk mendeskripsikan hasil belajar IPA siswa yang dilihat berdasarkan nilai rata-rata, standar deviasi dan sebaran nilai rata-rata hasil pretest dan posttest. Metode ANCOVA 1 jalur digunakan untuk mengetahui hubungan antara kovariat, yaitu pengetahuan awal siswa dengan hasil belajar siswa. Sebelum dilakukan pengujian hipotesis dengan ANCOVA 1 jalur terlebih dahulu data harus memenuhi beberapa asumsi. Asumsi-asumsi tersebut dilakukan dengan beberapa uji terhadap sebaran data yang meliputi: 1) Uji normalitas, 2) Uji homogenitas, 3) Uji linieritas dan keberartian garis regresi, dan 4) Uji homogenitas kemiringan garis regresi. Jika data hasil penelitian telah memenuhi persyaratan normalitas, homogenitas varian, linieritas dan homogenitas kemiringan garis regresi maka analisis ANCOVA 1 jalur dapat dilanjutkan. Pengujian hipotesis menggunakan uji ANCOVA 1 jalur dengan taraf signifikansi 0,05 dengan berbantuan SPSS 16.0 for windows. Kriteria pengujiannya adalah $\mathrm{H}_{0}$ ditolak jika $p<0,05$.

\section{HASIL DAN PEMBAHASAN HASIL}

Hasil penelitian yang dideskripsikan dalam penelitian ini adalah nilai rata-rata, standar deviasi, dan sebaran nilai rata-rata pretest dan posttest pada kelas eksperimen 1 dan kelas eksperimen 2.

Nilai rata-rata (M) dan standar deviasi (SD) hasil belajar IPA siswa pada kelas eksperimen 1 dan kelas eksperimen 2 sebelum pembelajaran (pretest) dan setelah pembelajaran (posttest) disajikan pada Tabel 1.

Tabel 1. Nilai Rata-rata dan Standar Deviasi

\begin{tabular}{ccccc}
\hline Model & \multicolumn{2}{c}{ Rata-rata } & \multicolumn{2}{c}{ Standar Deviasi } \\
\cline { 2 - 5 } Pembelajaran & Pretest & Posttest & Pretest & Posttest \\
\hline Kooperatif TPS & 36 & 80,46 & 7,60 & 5,69 \\
Kooperatif STAD & 36,26 & 62,34 & 7,73 & 7,03 \\
\hline
\end{tabular}

Berdasarkan Tabel 1 terlihat bahwa nilai rata-rata kemampuan awal (pretest) siswa pada kelas eksperimen 1 dan kelas eksperimen 2 memiliki nilai yang hampir sama. Hal tersebut mengindikasikan bahwa tingkat kemampuan awal siswa antara kelas eksperimen 1 dan kelas eksperimen 2 hampir sama. Standar deviasi pretest pada kelas eksperimen 1 tidak jauh berbeda dengan kelas eksperimen 2. Hal tersebut mengindikasikan bahwa sebaran data pada kelas eksperimen 1 dan kelas eksperimen 2 memiliki varian yang sama.

Setelah diberikan perlakuan, nilai rata-rata posttest pada kelas eksperimen 1 lebih tinggi daripada nilai rata-rata posttest kelas eksperimen 2. Hal tersebut 
mengindikasikan bahwa hasil belajar IPA siswa pada kelas eksperimen 1 lebih baik daripada kelas eksperimen 2. Standar deviasi posttest pada kelas eksperimen 2 lebih besar daripada kelas eksperimen 1. Hal tersebut mengindikasikan bahwa sebaran data pada kelas eksperimen 2 lebih bervariasi daripada kelas eksperimen 1.
Penelitian ini juga menganalisis sebaran nilai rata-rata masing-masing siswa sebelum (pretest) dan sesudah perlakuan (posttest) pada kelas eksperimen 1 dan kelas eksperimen 2 berdasarkan penilaian acuan patokan (PAP). Sebaran nilai rata-rata hasil belajar IPA siswa sebelum dan sesudah diberi perlakukan disajikan pada Tabel 2.

Tabel 2. Sebaran Nilai Rata-rata Hasil Belajar IPA Siswa

\begin{tabular}{cccccc}
\hline \multirow{2}{*}{$\begin{array}{c}\text { Interval } \\
\text { Nilai }\end{array}$} & Kualifikasi & \multicolumn{3}{c}{ Sebaran Nilai Rata-Rata Siswa (\%) } \\
\cline { 3 - 6 } & & \multicolumn{2}{c}{ Pretest } & \multicolumn{2}{c}{ Posttest } \\
\cline { 3 - 6 } & & TPS & STAD & TPS & STAD \\
\hline $85-100$ & Sangat tinggi & - & - & 25 & - \\
$70-84$ & Tinggi & - & - & 75 & 26,923 \\
$55-69$ & Cukup & - & - & - & 61,538 \\
$40-54$ & Rendah & 50 & 50 & - & 11,538 \\
$0-39$ & Sangat rendah & 50 & 50 & - & - \\
\hline
\end{tabular}

Berdasarkan Tabel 2 terlihat hasil sebaran nilai pretest siswa pada kelas eksperimen 1 dan kelas eksperimen 2 nilai rata-rata siswa hanya ada pada kategori rendah dan sangat rendah. Setelah diberikan perlakuan (posttest) sebaran nilai rata-rata siswa mengalami peningkatan. Hasil sebaran nilai posttest pada kelas eksperimen 1 mengalami peningkatan yang mencapai kategori sangat tinggi dan tinggi sedangkan kelas eksperimen 2 sebaran nilai rata-rata posttest siswa hanya mencapai kategori tinggi, cukup dan rendah dengan jumlah kategori rendah yang paling tinggi. Berdasarkan persentase tersebut menunjukkan bahwa sebaran nilai posttest siswa kelas eksperimen 1 lebih baik dibandingkan dengan kelas eksperimen 2.
Sebelum dilakukan uji hipotesis dengan ANCOVA 1 jalur, terlebih dahulu dilakukan uji asumsi yang meliputi: uji normalitas, uji homogenitas, uji linieritas dan uji homogenitas kemiringan garis regresi. Hasil uji asumsi menunjukkan bahwa data berdistribusi normal, memiliki varian data yang homogen, memiliki arah regresi yang berarti dan linier dan tidak terdapat interaksi antara kovariat (pengetahuan awal siswa) dengan variabel bebas (model pembelajaran). Berdasarkan hasil uji asumsi yang sudah dilakukan dapat disimpulkan bahwa data hasil penelitian telah memenuhi persyaratan sehingga uji hipotesis dilanjutkan dengan uji ANCOVA 1 jalur yang disajikan pada Tabel 3.

Tabel 3. Hasil Uji ANCOVA 1 jalur

\begin{tabular}{lrrrrr}
\hline \multicolumn{1}{c}{ Source } & $\begin{array}{c}\text { Type III Sum of } \\
\text { Squares }\end{array}$ & Df & Mean Square & F & Sig. \\
\hline Corrected Model & $4716.329^{\mathrm{a}}$ & 2 & 2358.164 & 57.985 & .000 \\
Intercept & 18202.533 & 1 & 18202.533 & 447.582 & .000 \\
Pengetahuan Awal & 5.079 & 1 & 5.079 & 66.125 & .000 \\
Model Pembelajaran & $\mathbf{2 8 0 6 . 3 0 6}$ & $\mathbf{1}$ & $\mathbf{2 8 0 6 . 3 0 6}$ & $\mathbf{6 9 . 0 0 4}$ & .000 \\
Error & 2236.775 & 55 & 40.669 & & \\
Total & 310512.000 & 58 & & & \\
Corrected Total & 6953.103 & 57 & & & \\
\hline
\end{tabular}


Berdasarkan Tabel 3 terlihat hasil uji ANCOVA 1 jalur yang menunjukkan nilai signifikansi pada lajur model pembelajaran lebih kecil dari 0,05 , sehingga keputusan yang dapat diambil adalah $\mathrm{H}_{0}$ ditolak. Hal ini

\section{PEMBAHASAN}

Hasil analisis menyatakan bahwa hasil belajar IPA siswa yang dibelajarkan menggunakan model pembelajaran kooperatif TPS pada kelas eksperimen 1 lebih tinggi dibandingkan dengan hasil belajar IPA siswa yang dibelajarkan menggunakan model pembelajaran kooperatif STAD pada kelas eksperimen 2.

Kemampuan awal siswa yang diukur menggunakan pretest merupakan variabel kovariat. Nilai rata-rata pretest kelas eksperimen 1 dan kelas eksperimen 2 menunjukkan nilai yang tidak jauh berbeda, yaitu 36 pada kelas eksperimen 1 dan 36,26 pada kelas eksperimen 2. Nilai ratarata pretest dapat dikendalikan sehingga tidak mempengaruhi hasil belajar IPA siswa. Hal tersebut dipertegas oleh uji interaksi pada pengaruh interaktif antara kemampuan awal siswa dan model pembelajaran yang memiliki angka signifikansi yang lebih besar dari 0,05. Berdasarkan hasil analisis tersebut, kemampuan awal siswa hanya dipengaruhi oleh model pembelajaran setelah dilakukan pengendalian terhadap variabel kovariat. $\mathrm{Hal}$ ini sejalan dengan dengan Trochim (2006) yang menyatakan bahwa variabel kovariat adalah variabel yang digunakan untuk menghilangkan atau mengurangi pengaruh pada analisis data yang disebabkan oleh variabel lain selain variabel yang diteliti sehingga efek dari variabel yang diteliti dapat terlihat dengan jelas. Setelah diberikan perlakuan, nilai rata-rata posttest pada kelas eksperimen 1 lebih tinggi daripada kelas eksperimen 2, yaitu 80,46 pada kelas eksperimen 1 dan 62,34 pada kelas eksperimen 2. Hasil tersebut menunjukkan bahwa model pembelajaran kooperatif TPS lebih efektif digunakan untuk meningkatkan hasil belajar siswa daripada model pembelajaran kooperatif STAD. Penelitian ini sejalan dengan penelitian Zakiah (2017) bahwa ada perbedaan yang signifikan antara hasil belajar siswa yang belajar menggunakan berarti bahwa terdapat perbedaan hasil belajar IPA antara siswa yang belajar dengan model pembelajaran kooperatif tipe TPS dan model pembelajaran kooperatif tipe STAD.

model pembelajaran kooperatif TPS (Think Pair Share) dari pada siswa yang belajar menggunakan model kooperatif STAD (Student Team Achievement Division).

Hasil belajar siswa yang lebih baik terdapat pada kelas eksperimen 1 yang dibelajarkan menggunakan model pembelajaran kooperatif TPS, karena kegiatan pembelajaran diawali oleh siswa yang berpikir (thinking) secara individu untuk menyelesaikan suatu permasalahan yang diberikan oleh guru. Hal tersebut mengindikasi bahwa kegiatan pembelajaran didominasi oleh siswa bukan oleh guru. Proses berpikir memiliki kontribusi besar dalam meningkatkan hasil belajar yang didapatkan siswa, karena saat kegiatan berpikir siswa diharuskan dapat menyelesaikan masalah dan dituntut untuk mengingat dan memahami terlebih dahulu permasalahan yang diberikan, kemudian mengkontruksikannya sehingga pada proses berpikir siswa dapat membiasakan diri untuk melatih kemampuan memahami dan memecahkan suatu permasalahan dengan menggunakan kemampuan sendiri sehingga siswa mampu mendapatkan hasil dan jawaban yang sesuai dengan permasalahan yang telah diberikan. Budiarto Cahyono (2017) memberikan gambaran bahwa proses berpikir merupakan proses yang bertujuan untuk memperoleh informasi (dari luar atau diri siswa), pengolahan, penyimpanan dan memanggil kembali informasi dari ingatan siswa, dengan demikian dapat dikatakan prinsip proses berpikir meliputi tiga langkah pokok yaitu pembentukan pengertian, pembentukan pendapat, dan penarikan kesimpulan, sehingga dengan melalui proses berpikir tingkat pengetahuan siswa akan menjadi lebih baik. Putri Anjarsari (2014) menyatakan bahwa proses berpikir merupakan keterampilan kognitif dan disposisi intelektual yang diperlukan siswa secara aktif untuk mengidentifikasi dan menganalisis argumen dan kebenaran 
untuk merumuskan dan memberi alasan yang tepat serta untuk mendukung kesimpulan dan membuat keputusan yang masuk akal tentang apa yang harus dilakukan. Yani Ramdani (2013) juga menyatakan bahwa proses berpikir dapat membantu siswa dalam membentuk konsep, menalar, berpikir kritis, membuat keputusan, berpikir kreatif, dan memecahkan masalah sehingga hasil belajar yang didapatkan siswa menjadi lebih optimal.

Dari hasil pemikiran secara individu, siswa kemudian dipasangkan dengan teman sebangkunya. Kegiatan berpasangan (pairing) memiliki kontribusi yang sama seperti proses berpikir karena pada proses ini siswa dituntut dapat membandingkan jawaban yang telah dipikirkan secara individu bersama pasangannya untuk mencari persamaan dan perbedaan pada hasil pemikiran dari masing-masing individu sehingga siswa terlatih untuk mengkomunikasikan pendapat atau gagasan mereka dalam menyelesaiakan permasalahan pada LKS serta berbagi informasi yang telah didiskusikan bersama masing-masing pasangan. Mulyana (2017) menyatakan bahwa melalui proses diskusi siswa dapat menjadi lebih aktif dan tidak sekedar melibatkan hubungan antara stimulus dan respon saja, melainkan melibatkan tingkah laku seseorang yang ditentukan oleh persepsi serta pemahamannya tentang situasi yang berhubungan dengan tujuan pembelajaran.

Dari hasil diskusi dengan pasangan, siswa berbagi informasi atau jawaban pada seluruh kelompok melalui kegiatan persentasi (sharing). Kegiatan ini membiasakan siswa untuk mengembangkan hasil pemikiran, ide-ide ataupun gagasan-gagasan yang mengarah pada penyelesaian dari permasalahan yang telah dibahas sebelumnya, sehingga hasil yang didapatkan siswa menjadi lebih baik dari sebelumnya. Saat berbagi jawaban siswa dituntut dapat menyusun dan dapat mengkategorikan jawaban yang telah disatukan dengan pasangannya sehingga jawaban yang akan dipersentasikan mudah dimengerti dan memiliki jawaban yang benar. Peran guru dalam hal ini hanya sebagai motivator dan evaluator. Halim $\mathrm{Hi}$ (2014) menyatakan bahwa proses berbagi informasi dan berdiskusi dapat mempermudah penyampaian materi dari guru kepada siswa, sehingga dapat memberikan suatu paradigma bahwa guru bukanlah satu-satunya sumber belajar sehingga dapat mempermudah penyampaian materi dari guru kepada siswa. Melalui proses diskusi dan persentasi siswa diberikan banyak ruang untuk meningkatkan aktivitas dan kreativitas mencari informasi terkait dengan materi yang disampaiakan. Sumiati Side (2013) juga menyatakan bahwa proses berdiskusi dan persentasi dapat memberikan dorongan kepada setiap anggota kelompok untuk berpikir kreatif dan menyumbangkan pengalaman dan keahliannya yang berguna untuk kepentingan bersama-sama. Berdasarkan kegiatan-kegiatan yang dilakukan siswa, dapat disimpulkan bahwa model kooperatif TPS memiliki kontribusi yang besar untuk meningkatkan hasil belajar siswa.

Model pembelajaran kooperatif STAD juga memiliki kontribusi dalam meningkatkan hasil belajar IPA siswa. Kontribusi model pembelajaran kooperatif STAD tidak sebesar model pembelajaran kooperatif TPS, karena proses awal pada kegiatan pembelajaran didominasi oleh kegiatan guru yang memberikan materi pelajaran kepada siswa. Hal ini kurang efektif dilakukan, karena proses pembelajaran dalam Kurikulum 2013 tidak menganjurkan guru mendominasi kegiatan pembelajaran, tetapi lebih mengutamakan peran siswa untuk lebih aktif dalam kegiatan pembelajaran di kelas. Pemberian materi diawal pembelajaran membuat siswa pasif dalam proses pembelajaran, karena proses pembelajaran hanya terjadi satu arah yaitu guru ke siswa saja (teacher center) sehingga peran siswa hanya sebagai penerima informasi. Hal ini tidak memaksimalkan kegiatan pembelajaran dalam kelas sehingga berdampak pada hasil belajar siswa yang kurang maksimal, karena materi pelajaran yang dijelaskan oleh guru pada awal pelajaran akan lewat begitu saja dan mudah dilupakan. Hal ini berbeda dengan kegiatan awal pada pembelajaran kooperatif TPS, siswa 
memang benar-benar dituntut untuk memikirkan dan mencari jawaban sendiri. Hal ini membuat daya ingatan siswa terhadap permasalahan yang terkait materi pelajaran dapat bertahan lama dibandingkan dengan proses awal pada kooperatif STAD. Novita Anggraini (2016) menyatakan bahwa guru hendaknya tidak lagi mengajar sebagai satu-satunya pemberi informasi dalam proses pembelajaran, guru hendaknya mengajar untuk membelajarkan siswa dalam konteks belajar seperti bagaimana belajar mencari, menemukan dan meresapi ilmu pengetahuan. Lubis (2012) menyatakan bahwa ketika guru berperan sepenuhnya dalam pembelajaran peserta didik tidak berkesempatan untuk mengembangkan pengetahuan mereka sendiri karena setiap masalah-masalah yang muncul dalam pembelajaran akan diselesaikan oleh guru, sehingga peserta didik menjadi pasif, sedangkan model pembelajaran yang digunakan oleh guru harus membuat siswa aktif dalam proses pembelajaran, karena keaktifan siswa dapat mempengaruhi hasil belajar. Dari hasil mendengarkan dan mencatat materi pelajaran, guru menganggap seluruh siswa sudah mengerti dan menguasai materi pelajaran yang telah diberikan di awal pelajaran, sehingga siswa langsung dikelompokkan menjadi beberapa kelompok dan secara berkelompok siswa mengerjakan LKS. Dalam proses menyelesaiakan permasalahan pada LKS, tidak semua siswa aktif dalam berdiskusi, karena kegiatan diskusi hanya didominasi oleh siswa yang pandai, sehingga siswa yang kurang mampu dalam pelajaran merasa enggan untuk berpendapat dan hanya menunggu jawaban temannya tanpa ikut berpartisipasi dalam diskusi. Oleh karena itu, upaya peningkatan hasil belajar IPA siswa masih kurang optimal. Diskusi kelompok seharusnya menjadi metode pengajaran yang paling efektif dalam kerja kelompok, khususnya mempelajari keterampilan yang kompleks seperti memikirkan secara kritis, pemecahan masalah dan komentar pribadi, pembelajaran metode diskusi dapat melaksanakan pertukaran gagasan, fakta dan pendapat antara murid, sehingga menjadikan suasana belajar lebih dinamis.
Dari hasil diskusi kelompok, selanjutnya siswa melakukan sharing dengan temanteman kelompoknya untuk mempersentasikan hasil pemikirannya dengan kelompok lain. Guru memiliki peran penting dalam proses persentasi, karena guru mengevaluasi hasil persentasi pada masing-masing kelompok untuk menyimpulkan jawaban mana yang benar, sehingga siswa hanya menjadi penerima informasi tanpa menelaah hasil jawaban yang telah dipersentasikan kelompok lain. Murwanti (2014) menyatakan peran guru hanya membantu siswa secara individu jika mengalami kesulitan untuk menentukan solusi dalam pemecahan masalah. Berdasarkan perbandingan tahapan yang berkontribusi untuk meningkatkan hasil belajar IPA siswa pada kelas eksperimen 1 dan kelas eksperimen 2, diketahui bahwa model pembelajaran kooperatif TPS memiliki kontribusi yang lebih baik dibandingkan model pembelajaran kooperatif STAD dalam meningkatkan hasil belajar siswa.

Hasil belajar IPA yang lebih baik pada kelompok pembelajaran TPS didukung oleh aktivitas siswa yang tergolong lebih aktif daripada siswa pada kelompok pembelajaran kooperatif STAD. Lusi Widayanti dan Widodo (2013) menyatakan bahwa penggunaan model pembelajaran yang tepat dapat menyebabkan perubahan aktivitas belajar siswa dari aktivitas belajar yang rendah menjadi aktivitas belajar yang tinggi.

Hasil penelitian ini belum tercapai secara maksimal karena masih terdapat beberapa kendala selama proses pembelajaran di kelas. Adapun kendala yang dialami dalam penelitian ini, yaitu keterbatasan alat dan bahan praktikum. Ketersediaan alat dan bahan praktikum dapat mempengaruhi proses pembelajaran di dalam kelas, karena alat dan bahan praktikum dapat dijadikan sebagai alat demonstrasi yang efektif untuk mempermudah siswa mengaitkan materi dengan kehidupan nyata. Jika ketersediaan alat dan bahan praktikum terbatas, maka proses pembelajaran juga tidak dapat berjalan dengan maksimal. Kendala tersebut berusaha diminimalisir dalam penelitian ini dengan cara setiap kelompok 
ditugaskan untuk membawa alat dan bahan praktikum sederhana agar proses belajar mengajar menjadi lebih bermakna.

\section{PENUTUP}

Berdasarkan hasil penelitian dan pembahasan temuan dalam penelitian ini menyatakan bahwa terdapat perbedaan yang signifikan hasil belajar IPA antara kelompok siswa yang menggunakan model pembelajaran kooperatif tipe TPS dan kelompok siswa yang menggunakan model pembelajaran kooperatif tipe STAD. Hasil analisis ANCOVA 1 jalur menunjukkan bahwa nilai signifikansi lebih kecil dari 0,05. Kualifikasi hasil belajar IPA siswa yang menggunakan model pembelajaran tipe TPS berada pada kategori tinggi sedangkan hasil belajar IPA siswa yang menggunakan model pembelajaran tipe STAD berada pada kategori rendah. Maka dapat disimpulkan bahwa hasil belajar IPA siswa yang dibelajarkan menggunakan model pembelajaran tipe TPS lebih baik dari pada siswa yang dibelajarkan menggunakan model pembelajaran tipe STAD.

\section{SARAN}

Saran yang dapat disampaikan berdasarkan penelitian yang telah dilakukan adalah untuk praktisi pendidikan khususnya yang terlibat dalam pembelajaran IPA disarankan untuk mempertimbangkan model pembelajaran kooperatif TPS sebagai salah satu alternatif model pembelajaran yang dapat diterapkan di kelas terutama apabila ingin meningkatkan hasil belajar IPA siswa. Penelitian ini hanya bertujuan untuk mengetahui adanya pengaruh model pembelajaran terhadap hasil belajar IPA siswa.

Kepada peneliti lain yang tertarik untuk melakukan penelitian dengan model pembelajaran kooperatif TPS disarankan melakukan penelitian pada aspek pembelajaran yang berbeda, misalnya berpikir kritis, motivasi belajar, keterampilan proses sains, dan kemampuan pemecahan masalah. Penelitian ini hanya dilakukan pada sampel dan materi pembelajaran yang terbatas. Peneliti lain disarankan untuk melakukan penelitian terhadap model pembelajaran kooperatif TPS dengan sampel yang lebih besar dan materi yang lebih luas untuk mengetahui pengaruh penerapan model pembelajaran kooperatif TPS dalam pembelajaran IPA secara lebih mendalam.

\section{DAFTAR RUJUKAN}

Anjarsari, P. 2014. Pentingnya Melatih Keterampilan Berpikir (Thinking Skills) dalam Pembelajaran IPA SMP. Yogyakarta. UNY. Tersedia pada: staff.uny.ac.id>purianjarsari-ssi-mpd. Diakses pada tanggal 20 Juni 2018

Anggraini, N. 2016. Peran Guru dalam Proses Pembelajaran. Tersedia pada:https://www.kompasiana.com /nopitaanggraini0311/peran-gurudalam-proses-pemblajaran.

Diakses pada tanggal 20 Juni 2018.

Arikunto, S. 2006. Prosedur Penelitian Suatu Pendekatan Praktik. Jakarta:Rineka Cipta.

Asyah, N. 2014. Penerapan Model Kooperatif Tipe Think Pair Share pada prestasi belajar. Jurnal Pendidikan Kimia., 1(1), 25-32. Tersediapada:jurnal.etd.unsyiah.ac .id/2014/index.php?p=show_detail \&id=4065.Diakses pada tanggal 11 Januari 2018.

Bamoro, A O. 2015. Effects of Guided Discovery and Think-Pair-Share Strategies on Secondary School Students' Achievement in Chemistry. Nigeria Tai of Education. 1(10), 1-7. Tersedia pada:http://journals.sagepub.com/do i/abs/10.1177/2158244014564754.

Diakses pada tanggal 5 November 2017.

Cahyono. B. 2017. Analisis Keterampilan Berpikir Kritis dalam memecahkan masalah Ditinjau daru Gender. Semarang. UIN Walisongo. Tersedia pada: https://media.neliti.com. Diakses pada tanggal 20 Juni 2018 
Disdikpora. Data Nilai UN tahun 2016-2017

Se-Bali. Bali. Tersedia pada disdikpora.baliprov.go.id/SerahTerima-Daftar-Kolektif-Nilai-UjianNasional.html. Diakses pada tanggal 20 November 2017.

Karlina, I. Artikel Pembelajaran Koopertif STAD sebagai salah satu Membangun Strategi Belajar Siswa. 1(2), 47-52. Tersedia pada: https//repository.uksw.edu/bistream.

Diakses pada tanggal 5 November 2017.

Lubis. A. 2012. Pengaruh Model Pembelajaran Kooperatif Tipe STAD Terhadap Hasil Belajar Fisika Siswa pada Materi Pokok Gerak Lurus di Kelas X SMA Swasta UISU Medan. Jurnal Pendidikan Fisika., 1 (1), 2732. Tersedia pada: jurnal.unimed.ac.id/2012/index.php/j pf/article/view/3378. Diakses pada tanggal 11 November 2017.

Mulyana. A. 2015. Perbedaan Kemampuan berpikir kreatif matematis siswa dengan inquiri learning dan discovery learing di SMP N 57 Jakarta. Sigma Jurnal. The jurnal of education mathematics, science and technology. 11(02), issn. 1411-516.

Putra, W. 2017. Konferensi Pers UN 2017 Jenjang SMP. Tersedia pada: www.academia.edu/34731861/konf erensi pers UN 2017 Jenjang SMP. Diakses pada tanggal 18 Juni 2018.

Ramdani, Y. 2014. Pembelajaran Saintifik debate untuk meningkatkan kemampuan berpikir kreatif mahasiswa. Bandung. UNISBA. Tersedia pada: https//media.neliti.com/Pembelajar an-

Saintififdebate_untuk_meningkatka n_kemampuan_berpikir_kreatif_ma hasiswa. Diakses pada tanggal 20 Juni 2018.
Side. S, Hardin \& Tanrere M. 2013. Penerapan Metode Diskusi Berkelanjutan Mata Pelajaran Kimia untuk Meningkatkan Keaktifan dan Hasil Belajar Siswa Kelas XI IPA $A_{6}$ SMA Negeri 11 Makassar. Makassar. Universitas Negri Makassar. Jurnal Chemica. 14(1), 46-54. Tersedia pada: portalgaruda.org >articel-sumiati-

side-2013. Diakses pada tanggal 18 Juni 2018.

Sulistiono, A. 2014. Penerapan pendekatan saintific dengan media roalia untuk meningkatkan hasil belajar matematika siswa kelas $v$ SD negeri Blotongan 03 Kecamatan Sidorejo Kota Salatiga. Pendidikan Guru Sekolah Dasar FKIP. UKSW. Tersedia pada: https//scholar.google.co.id/scholar? q=sulistino+2014+proses+berpikird zmdwjlwzbs8J. Diakses pada tanggal 20 Juni 2018.

Surayya, L., Subagia, I W \& Tika, I N. 2014. Pengaruh Model Pembelajaran Think Pair Share Terhadap Hasil Belajar IPA Ditinjau Dari Keterampilan Berpikir Kritis Siswa. Singaraja. Universitas Pendidikan Ganesha. e-Journal Program Pascasarjana Universitas Pendidikan Ganesha., 4 (1), 1-11. Tersedia pada: pasca.undiksha.ac.id/ejournal/index.php/jurnal_ipa/article/vi ew/110. Diakses pada tanggal 5 November 2017.

Trochim, W M K. (2006). The non equivalent group design. Tersedia pada:http://www.socialresearchmeth ods.net/kb/quasnegd.php. Diakses pada tanggal 9 Juni 2018.

Undang-Undang Republik Indonesia No. 20 Tahun 2003 tentang sistem pendidikan nasional. Tersedia pada:http://kelembagaan.ristekdikti .go.id/wpcontent/uploads/2016/08/ UU_no_20_th_2003.pdf.Diakses pada tanggal 2 Oktober 2017. 
Widayanti, L \& Widodo M. 2013. Peningkatan Aktivitas Belajar dan Hasil Belajar Siswa dengan Metode Problem Based Learning pada Siswa Kelas VIIA MTs Negeri Donomulyo Kulon Progo Tahun Pelajaran 2012/2013. Yogyakarta. Universitas Ahmad Dahlan. Jurnal Fisika Indonesia. 17(49), 32-35. Tersedia pada: http://pdmmipa.ugm.ac.id/ojs/index.php/ji/artic le/view/831/910. Diakses pada tanggal 20 Juni 2018.

Zamroni, B \& Sujadi, I. 2016. Eksprimentasi Pembelajaran Kooperatif Tipe TPS dan STAD dengan Pendekatan CTL pada Materi Pokok Sistem Persamaan Linear Dua Variabel Ditinjau Dari Gaya Belajar Siswa. Surakarta. Universitas Sebelas Maret . Jurnal Pembelajaran Matematika. 1(3), 306-316.

Zakiah, M \& Enawati, E. 2017. Pengaruh Model TPS terhadap Aktivitas dan Hasil belajar pada materi redoks. Pontianak. Untan Pontianak. Diakses pada tanggal 20 Juni 2018. 